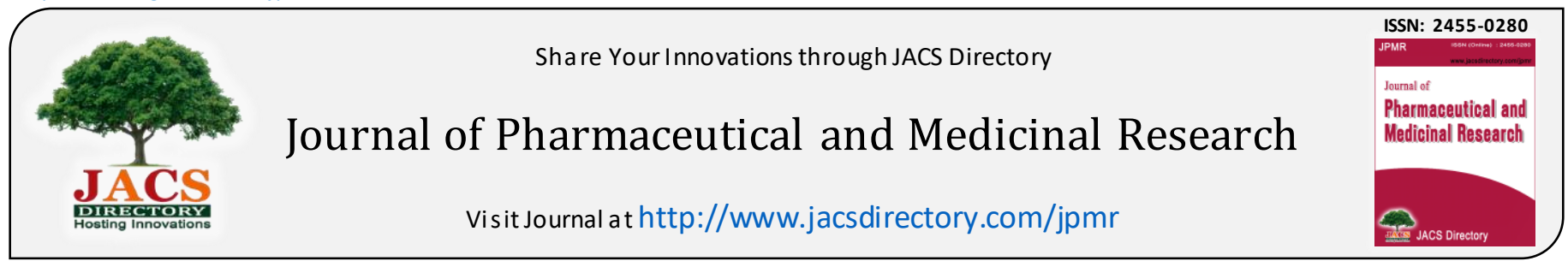

\title{
Indigenous Knowledge on Cattle Health Care Practices in Selected Villages of Madurai District in Tamil Nadu, India
}

\author{
S. Sarguna Sundaram*, K. Suresh \\ Post Graduate and Research Departmentof Botany, Saraswathi Narayanan College, Perungudi, Madurai - 625 022, Tamil Nadu, India.
}

\section{ARTICLE DETAILS}

Article history:

Received 24 December 2018

Accepted 08 January 2019

Available online 26 January 2019

Keywords:

Cattle Diseases

Medicinal Plants

Madurai District

\begin{abstract}
A B S T R A C T
The present study was aimed to investigate the Indigenous knowledge on cattle health care practices in selected villages located in foot bases of Azhagar hills in Madurai district, Tamil Nadu. The informations related to ethnoveterinary practices were collected through questionnaire as well as personal interviews during field trips made from August, 2014 to June, 2018. It has been shown that 41 medicinal plants of 24 families used by traditional healers to cure cattle diseases were documented from study sites. The ancestral traditional knowledge of people who have been using the native plants for the preparation of drugs and methods of their administration were recorded. From this present investigation, the practical knowledge of people in herbal medicines reveals that they are capable of treating various diseases.
\end{abstract}

\section{Introduction}

Medicinal plants are being used for the treatment of various livestock ailments by the local peoples since earliest times. It is a recognized fact that plants are an important source of ethnoveterinary medicines [1]. From the last decade, ethnoveterinary practices have gained tremendous importance due to the discovery of some effective ethnoveterinary practices are more common in developing countries [2,3]. The aim of the present investigation was to record the indigenous knowledge of local people on medicinal plants used for curing cattle diseases in 4 different villages located at the foothills of Azhagar hills in Madurai district.

\section{Experimental Methods}

\subsection{Geographical Details of the Study Sites}

For this current research work, a total of 4 villages viz., Arittapatti $\left(78^{\circ}\right.$ $16^{\prime} 42^{\prime \prime}$ E Longitude - $10^{\circ} 02^{\prime} 11^{\prime \prime} \mathrm{N}$ Latitude), A.Vallalapatti $\left(78^{\circ} 17^{\prime} 11^{\prime \prime} \mathrm{E}\right.$ Longitude $-10^{\circ} 03^{\prime} 38^{\prime \prime} \mathrm{N}$ Latitude), Kidaripatti ( $78^{\circ} 15^{\prime} 27^{\prime \prime}$ E Longitude $-10^{\circ} 03^{\prime} 52^{\prime \prime} \mathrm{N}$ Latitude) and Mangulam (78 $16^{\prime} 24^{\prime \prime}$ E Longitude - $10^{\circ} 03^{\prime}$ 11 " N Latitude), which are located at the foot hills of Azhagar hills in Madurai district of Tamil Nadu, were selected. The altitude of the study sites is about $350-430 \mathrm{M}$ above mean sea level (MSL).

\subsection{Weather Details}

As all the study sites selected for this present investigation were located within the distance of $10 \mathrm{~km}$ in total, there is no any fluctuations in temperature and rainfall of the study sites. The temperature of the study area ranges from $20^{\circ} \mathrm{C}$ during winter and about $39^{\circ} \mathrm{C}$ during summer. The average rainfall reaches $700 \mathrm{~mm}$ per year.

\subsection{Interview with Informants}

In order to document the utilization of the plants presented in selected study sites as veterinary medicine by the local inhabitants of different regions, an extensive survey was carried out in 4 villages from August, 2014 to June, 2018. A standard method was followed to collect the valuable information on veterinary medicine [4]. The informants interviewed numbered 17 (12 Male, 5 Female) which include both

households and herbalist healers who had strong links with traditional activities. The age of the informants was ranged $37-72$.

\subsection{Botanical Identification of Plants}

All the medicinal plants recorded during thefield visits were botanically identified by referring Flora of Tamil Nadu Carnatic [5] and An Excursion Flora of Central Tamil Nadu, India [6].

\section{Results and Discussion}

By the present investigation, it was observed that the ethnoveterinary use(s) of 41 species belonging to 41 genera under 24 families (Table 1 ). Among the 41 species recorded, dicots were represented by 36 species belonging to 36 genera of 21 families and monocots were 5 species of 5 genera belonging to 3 families (Table 2 ).

The results of current research work also reveals that the family Asclepiadaceae was found as dominant one with 5 species and it was followed by Caesalpiniaceae, Fabaceae, Liliaceae and Solanaceae: each was represented with 3 species. The following 5 families viz. Acanthaceae, Amaranthaceae, Anacardiaceae, Euphorbiaceae and Rutaceae were recorded with 2 species each and remaining 14 families were reported as monospecific family (Table 2).

By the present investigation, it was also noted that, regarding the plant parts used, leaf was the mostly used plant part (in 21 preparations with $43.75 \%$ ) to treat a particular disease followed by whole plant (in 6 preparations with $12.5 \%$ ), fruit (in 4 preparations with $8.33 \%$ ), latex (in 3 preparations with $6.26 \%$ ), root (in 3 preparations with $6.26 \%$ ), inflorescence(in 3 preparations with 6.26\%)and seed (in 2 preparations with 4.16\%). Bulb, leaf gel, stem, stem bark, twig and tuber were the least used part (in 1 preparation with $2.08 \%$ each) (Fig. 1).

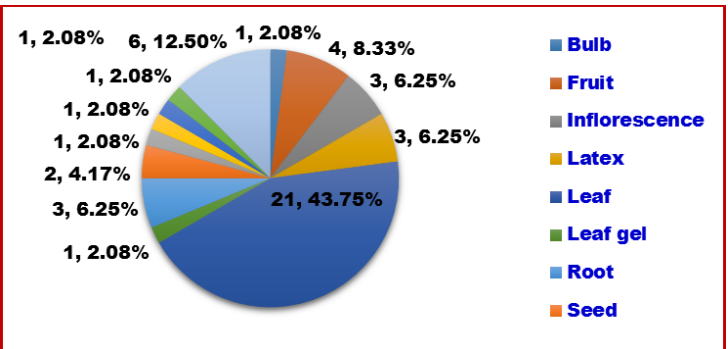

Fig. 1 Number and Percent distribution of plant parts used 
Table 1 Ethnoveterinary medicinal plants used in the study sites

\begin{tabular}{|c|c|c|c|c|}
\hline $\begin{array}{l}\text { S. } \\
\text { No. }\end{array}$ & Binomial Name & Family & $\begin{array}{l}\text { Local Name } \\
\text { (Tamil) }\end{array}$ & Uses \\
\hline$\overline{1}$ & $\begin{array}{l}\text { Abrus } \\
\text { precatorius } \mathrm{L} .\end{array}$ & Fabaceae & Kundumani & $\begin{array}{l}\text { Whole plant is given } \\
\text { orally for dysentery }\end{array}$ \\
\hline 2 & $\begin{array}{l}\text { Abutilon } \\
\text { indicum(L.) } \\
\text { Willd ex DC. }\end{array}$ & Malvaceae & Thuthi & $\begin{array}{l}\text { Roots fed each day to } \\
\text { lactating cows }\end{array}$ \\
\hline 3 & $\begin{array}{l}\text { Acalyphaindica } \\
\text { L. }\end{array}$ & Euphorbiaceae & Kuppaimeni & $\begin{array}{l}\text { Leaf paste with pepper } \\
\text { applied for skin diseases }\end{array}$ \\
\hline 4 & $\begin{array}{l}\text { Achyranthesaspe } \\
\text { ra L. }\end{array}$ & Amaranthaceae & Naayuruvi & $\begin{array}{l}\text { Leaf paste is applied to } \\
\text { genital part and allowed } \\
\text { to inhale the same for } \\
\text { easy delivery }\end{array}$ \\
\hline 5 & $\begin{array}{l}\text { Adhatodavasica } \\
\text { Nees }\end{array}$ & Acanthaceae & Adhatoda & $\begin{array}{l}\text { Decoction of leaves and } \\
\text { stem is used to cure } \\
\text { fever and skin diseases }\end{array}$ \\
\hline 6 & $\begin{array}{l}\text { Aegle } \\
\text { marmelosCorr. }\end{array}$ & Rutaceae & Vilvam & $\begin{array}{l}\text { Leaf juice is used for foot } \\
\text { and mouth diseases }\end{array}$ \\
\hline 7 & Allium cepa $\mathrm{L}$. & Liliaceae & Vengayam & $\begin{array}{l}\text { Bulb Paste is applied in } \\
\text { insects bites to relieve pain }\end{array}$ \\
\hline 8 & $\begin{array}{l}\text { Aloe vera(L.) } \\
\text { Burm.f. }\end{array}$ & Liliaceae & Katthalai & $\begin{array}{l}\text { Leaf gel is fed to cure } \\
\text { wound healing and skin } \\
\text { diseases }\end{array}$ \\
\hline 9 & $\begin{array}{l}\text { Amaranthusspin } \\
\text { osus L. }\end{array}$ & Amaranthaceae & Mullukkirai & $\begin{array}{l}\text { Whole plants are used as } \\
\text { forage to increase the } \\
\text { yield of milk }\end{array}$ \\
\hline 10 & $\begin{array}{l}\text { Anacardiumoccid } \\
\text { entale L. }\end{array}$ & Anacardiaceae & $\begin{array}{l}\text { Andimaparu } \\
\text { ppu }\end{array}$ & $\begin{array}{l}\text { The twig is fed to cure } \\
\text { trachoma }\end{array}$ \\
\hline 11 & $\begin{array}{l}\text { Andrographispan } \\
\text { iculata Nees }\end{array}$ & Acanthaceae & Nilavembu & $\begin{array}{l}\text { Whole plant decoction is } \\
\text { used for fever and cough }\end{array}$ \\
\hline 12 & $\begin{array}{l}\text { Aristolochia } \\
\text { bracteolata Lam. }\end{array}$ & Aristolochiaceae & $\begin{array}{l}\text { Aduthinnnap } \\
\text { palai }\end{array}$ & $\begin{array}{l}\text { Leaf is given orally for } \\
\text { insect bite }\end{array}$ \\
\hline 13 & $\begin{array}{l}\text { Azadirachta } \\
\text { indica A. juss }\end{array}$ & Meliaceae & Vembu & $\begin{array}{l}\text { Leaf extract is used as an } \\
\text { insecticide }\end{array}$ \\
\hline 14 & $\begin{array}{l}\text { Bauhinia } \\
\text { variegata L. }\end{array}$ & Caesalpiniaceae & Manthaarai & $\begin{array}{l}\text { Stem bark decoction is } \\
\text { used to wash foot and } \\
\text { mouth wound }\end{array}$ \\
\hline 15 & $\begin{array}{l}\text { Borassus } \\
\text { flabellifer } \mathrm{L} .\end{array}$ & Arecaceae & Panai & $\begin{array}{l}\text { Inflorescence is given } \\
\text { orally for cure dysentery }\end{array}$ \\
\hline 16 & $\begin{array}{l}\text { Calotropi } \\
\text { sprocera Ait }\end{array}$ & Asclepiadaceae & Erukku & $\begin{array}{l}\text { Latex is applied externally } \\
\text { for wound healing }\end{array}$ \\
\hline 17 & $\begin{array}{l}\text { Capsicum annum } \\
\text { L. }\end{array}$ & Solanaceae & Milagaai & $\begin{array}{l}\text { Fruit extract is used to } \\
\text { cure spleen disease }\end{array}$ \\
\hline 18 & Carica papaya L. & Caricaceae & Pappali & $\begin{array}{l}\text { Leaf and fruit is given } \\
\text { orally for indigestion }\end{array}$ \\
\hline 19 & $\begin{array}{l}\text { Cassia auriculata } \\
\text { L. }\end{array}$ & Caesalpiniaceae & Aavaarai & $\begin{array}{l}\text { Leaf and flower paste is } \\
\text { applied for tumor and } \\
\text { skin diseases }\end{array}$ \\
\hline 20 & $\begin{array}{l}\text { Cissusqua } \\
\text { drangularis L. }\end{array}$ & Vitaceae & Pirandai & $\begin{array}{l}\text { The plant is crushed and } \\
\text { tied on the placenta after } \\
\text { delivery to hasten } \\
\text { removal of placenta }\end{array}$ \\
\hline 21 & $\begin{array}{l}\text { Citrus limon (L.) } \\
\text { Burm.f. }\end{array}$ & Rutaceae & Narthangaai & $\begin{array}{l}\text { Fruit juice is applied } \\
\text { externally for relieving } \\
\text { irritation of insect bites }\end{array}$ \\
\hline 22 & $\begin{array}{l}\text { Coriandrum } \\
\text { sativum L. }\end{array}$ & Apiaceae & Kothamalli & $\begin{array}{l}\text { Whole plant is used for } \\
\text { loose motion }\end{array}$ \\
\hline 23 & $\begin{array}{l}\text { Cyperus rotundus } \\
\text { L. }\end{array}$ & Cyperaceae & Korai & $\begin{array}{l}\text { Leaf paste is externally } \\
\text { applied for tick and lice } \\
\text { infestation }\end{array}$ \\
\hline 24 & Datura metal L. & Solanaceae & Oomatham & $\begin{array}{l}\text { Tender leaf juice mixed } \\
\text { with sugar and water is } \\
\text { given once daily for two } \\
\text { days to prevent rabies }\end{array}$ \\
\hline 25 & $\begin{array}{l}\text { Eclipta } \\
\text { prostrataL. }\end{array}$ & Asteraceae & $\begin{array}{l}\text { Karisalangan } \\
\text { ni }\end{array}$ & $\begin{array}{l}\text { Leaf paste is applied for } \\
\text { wound healing }\end{array}$ \\
\hline 26 & $\begin{array}{l}\text { Euphorbia hirta } \\
\text { L. }\end{array}$ & Euphorbiaceae & $\begin{array}{l}\text { Amman } \\
\text { patcharisi }\end{array}$ & $\begin{array}{l}\text { Latex is applied on } \\
\text { wounds }\end{array}$ \\
\hline 27 & $\begin{array}{l}\text { Ficus } \\
\text { benghalensis L. }\end{array}$ & Moraceae & Aalamaram & $\begin{array}{l}\text { Leaf extract with } \\
\text { common salt are rubbed } \\
\text { on tongue to cure sore of } \\
\text { cow and bullock }\end{array}$ \\
\hline 28 & $\begin{array}{l}\text { Gloriosa superba } \\
\text { L. }\end{array}$ & Liliaceae & Kanthal & $\begin{array}{l}\text { Tuber powder and leaf } \\
\text { extract used for curing } \\
\text { pain delivery and } \\
\text { trouble in urination }\end{array}$ \\
\hline
\end{tabular}

https://doi.org/10.30799/jpmr.037.19040101

\begin{tabular}{|c|c|c|c|c|}
\hline 29 & $\begin{array}{l}\text { Gymnema } \\
\text { sylvestre (Retz.) }\end{array}$ & Asclepiadaceae & Sirukurinchan & $\begin{array}{l}\text { Leaf juice is used as eye } \\
\text { drop }\end{array}$ \\
\hline 30 & $\begin{array}{l}\text { R.Br. } \\
\text { Hemides } \\
\text { musindicus (L.) } \\
\text { R.Br }\end{array}$ & Asclepiadaceae & Nannari & $\begin{array}{l}\text { The root infusion is used } \\
\text { to protect cattle from } \\
\text { insect diseases }\end{array}$ \\
\hline 31 & $\begin{array}{l}\text { Mangifera indica } \\
\text { L. }\end{array}$ & Anacardiaceae & Mamaram & $\begin{array}{l}\text { Seeds are given raw to } \\
\text { cure dysentery }\end{array}$ \\
\hline 32 & $\begin{array}{l}\text { Lawsonia } \\
\text { inermis L. }\end{array}$ & Lythraceae & Maruthani & $\begin{array}{l}\text { Leaf decoction is } \\
\text { prescribed for } \\
\text { constipation }\end{array}$ \\
\hline 33 & Leucas aspera $\mathrm{L}$. & Lamiaceae & Thumbai & $\begin{array}{l}\text { Whole plant with pepper } \\
\text { is given orally to cattle } \\
\text { as a cure for snake bite }\end{array}$ \\
\hline 34 & $\begin{array}{l}\text { Maduca indica } \\
\text { J.F. Gmel. }\end{array}$ & Sapotaceae & Illupai & $\begin{array}{l}\text { Flower oil is applied on } \\
\text { chronic wounds to expel } \\
\text { worms }\end{array}$ \\
\hline 35 & $\begin{array}{l}\text { Millettia extensa } \\
\text { Benth. }\end{array}$ & Fabaceae & $\begin{array}{l}\text { Poona } \\
\text { maram }\end{array}$ & $\begin{array}{l}\text { Crushed leaves spread } \\
\text { on cattle shed to cure } \\
\text { foot diseases }\end{array}$ \\
\hline 36 & $\begin{array}{l}\text { Percularia } \\
\text { daemia Forssk. }\end{array}$ & Asclepiadaceae & Veliparuthi & $\begin{array}{l}\text { Latex is used to cure ring } \\
\text { worm and skin diseases }\end{array}$ \\
\hline 37 & $\begin{array}{l}\text { Pongamia } \\
\text { pinnata Pierre }\end{array}$ & Fabaceae & Pungam & $\begin{array}{l}\text { Leaf paste is used for } \\
\text { wound healing. Seed oil } \\
\text { is used for wound } \\
\text { healing and skin } \\
\text { diseases }\end{array}$ \\
\hline 38 & $\begin{array}{l}\text { Tamarindus } \\
\text { indica } \mathrm{L} .\end{array}$ & Caesalpiniaceae & Puliamaram & $\begin{array}{l}\text { Leaf paste is applied for } \\
\text { wounds }\end{array}$ \\
\hline 39 & $\begin{array}{l}\text { Tylospora indica } \\
\text { Burm.f. }\end{array}$ & Asclepiadaceae & $\begin{array}{l}\text { Nancharupp } \\
\text { an }\end{array}$ & $\begin{array}{l}\text { Leaves are given orally } \\
\text { to cure digestion } \\
\text { problems }\end{array}$ \\
\hline 40 & Vitex negundo L. & Verbenaceae & Nochi & $\begin{array}{l}\text { Leaves juice is used to } \\
\text { discharge worms from } \\
\text { stomach }\end{array}$ \\
\hline 41 & $\begin{array}{l}\text { Withania } \\
\text { somnifera } \mathrm{L} .\end{array}$ & Solanaceae & Amukkara & $\begin{array}{l}\text { Root juice is used to cure } \\
\text { diarrhea }\end{array}$ \\
\hline
\end{tabular}

Table 2 Family distribution of ethnoveterinary plants

\begin{tabular}{|c|c|c|c|}
\hline S. No. & Family & No. of genus & No. of species \\
\hline 1 & Acanthaceae & 2 & 2 \\
\hline 2 & Amaranthaceae & 2 & 2 \\
\hline 3 & Anacardiaceae & 2 & 2 \\
\hline 4 & Apiaceae & 1 & 1 \\
\hline 5 & Arecaceae* & 1 & 1 \\
\hline 6 & Aristolochiaceae & 1 & 1 \\
\hline 7 & Asclepiadaceae & 5 & 5 \\
\hline 8 & Asteraceae & 1 & 1 \\
\hline 9 & Caesalpiniaceae & 3 & 3 \\
\hline 10 & Caricaceae & 1 & 1 \\
\hline 11 & Cyperaceae* & 1 & 1 \\
\hline 12 & Euphorbiaceae & 2 & 2 \\
\hline 13 & Fabaceae & 3 & 3 \\
\hline 14 & Lamiaceae & 1 & 1 \\
\hline 15 & Liliaceae* & 3 & 3 \\
\hline 16 & Lythraceae & 1 & 1 \\
\hline 17 & Malvaceae & 1 & 1 \\
\hline 18 & Meliaceae & 1 & 1 \\
\hline 19 & Moraceae & 1 & 1 \\
\hline 20 & Rutaceae & 2 & 2 \\
\hline 21 & Sapotaceae & 1 & 1 \\
\hline 22 & Solanaceae & 3 & 3 \\
\hline 23 & Verbenaceae & 1 & 1 \\
\hline 24 & Vitaceae & 1 & 1 \\
\hline
\end{tabular}

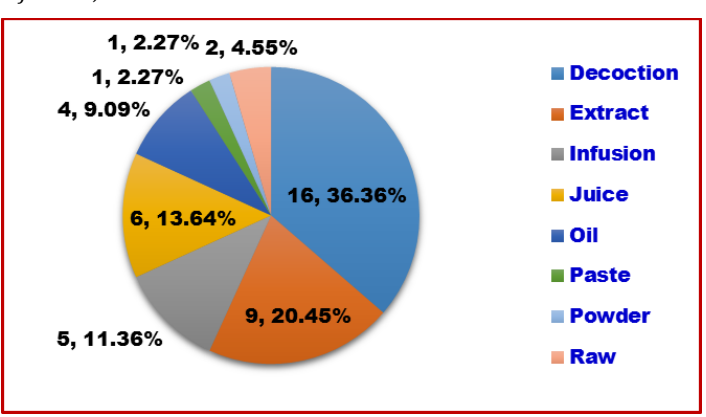

Fig. 2 Number and Percent distribution of mode of preparation 
Based on the data collected for the present investigation, the preparation of plant parts for administration was assembled into the following categories. The medicinal preparation was mostly used in the form of raw (no. of cases 16: use percentage $36.37 \%$ ), and paste (9: $20.45 \%$ ). It was followed by juice (6: $13.63 \%$ ), decoction (5: $11.37 \%$ ), extract (4: $9.09 \%)$ and oil (2: $4.55 \%)$. The 2.27 percentage with 1 case of preparation mode was recorded for powder and infusion each as least (Fig. 2).

The findings of the present investigation also revealed that the administration routes were mainly applied externally (no. of case 16: percent distribution 38.10), given to eat (11: $26.20 \%)$, taken as drink (9: $21.42 \%$ ), inhale (1: $2.38 \%$ ), pour (1: $2.38 \%$ ), spread (1: $2.38 \%)$, wash (1: 2.38\%) and tie (1: 2.38\%) (Fig. 3)

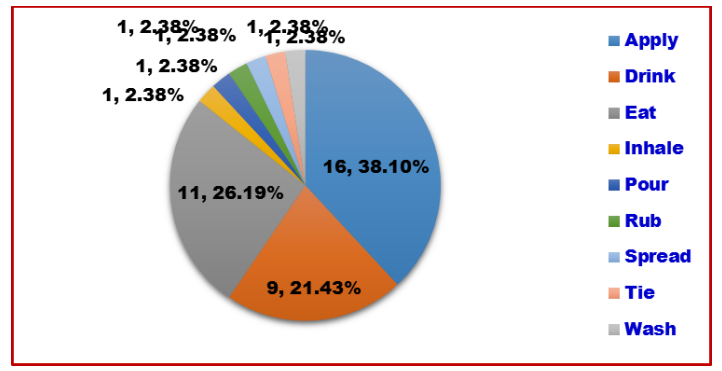

Fig. 3 Number and Percent distribution of mode of administration

From the current research work, it was stated that the medicinal resources were collected from wild and used to cure veterinary ailments. The studies conducted in other parts of India by the workers, like Saikia and Borthakur [3] in Assam, Galav et al. [7] in Rajasthan, also supportthe results of present study.

Theresults of presentinvestigationalso exposes that thetrends ofusing traditionally available medicinal plants were found more in upper age class in both gender as compared to younger generation. The studies carried out by some more researchers also indicated that the rural people especially the aged informants have tremendous knowledge on veterinary medicinal plants [8-11]

The monumental research works, conducted by Kiruba et al. [12] from Cape Comorin of Tamil Nadu, Dar and Verma [13] among rural people of Jhanshi district of Buldelkhand, Selvaraju et al. [14] from Malayali tribes living in Salem district of Tamil Nadu, Muley et al. [15] in Ahmednagar district of Maharashtra and Pragada and Rao [16] in tribal regions of Andhra Pradesh, have been resulted in leaves were mostly used plant parts for the preparation of veterinary medicine. The observations of current research works also corroborated with the same of above mentioned works.

\section{Conclusion}

The rural population of study areas owns one or two cows, goats which are used either for agricultural purposes or for selling to generate extra income. For treatment of cattle diseases, they rely on traditionally healers who use medicinal plants to treat cattle ailments. Locally communities especially, older age generally use these traditionally available medicinal plants for curing their cattle because these are easily available, less expensive, and have no side effects. Under these circumstances, a way must be found to salvage and record this priceless indigenous knowledge with the view to ascertaining its usefulness in the designing and development of a viable and sustainable animal health program with a more developed system of ethnoveterinary medicines. Further research analysis were urgently need on the aspects of phytochemistry, biological and clinical studies on these ethnoveterinary important medicinal plants.

\section{Acknowledgement}

The authors are cordially thankful to the informants for their kind support and giving valuable data on ethnoveterinary medicinal plants during our field visits.

\section{References}

[1] K.N. Reddy, V.R. Raju, Plants in Ethnoveterinary practices in Anatapur district, Andhra Pradesh, J. Econ. Taxon. Bot. 23 (1999) 357-357.

[2] K.C. Dash, U.K. Sahoo, P. Rocky, Utilization of forest products as livestock feed J. North-Eastern Counc. 24 (2004) 15-19.

[3] B. Saikia, S.K. Bothakur, Use of medicinal plants in animal health care - A case study from Gohpur, Assam, Indian J. Trad. Knowl. 9(1) (2010) 49-51.

[4] S.K. Jain, The role of botanist in folklore research, Folklore 5 (1964) 145-150.

[5] K.M. Matthew, Flora of Tamilnadu carnatic, The Rapinat Herbarium, St. Joseph's College, Tiruchirapalli, Tamil Nadu, 1981-1983.

[6] K.M. Matthew, An excursion flora of Central Tamil Nadu, Oxford - IBH Publishing Co. Pvt. Ltd., New Delhi, 1991.

[7] P. Galav, A. Jain, S.S. Katewa, A. Nag, Animal healthcare practices by livestock owners at Pushkar animal fair, Rajasthan, Indian J. Trad. Knowl. 9(4) (2010) 660-663.

[8] K.B. Satapathy, Ethnoveterinary practices in Jajpur district of Orissa, Indian J. Trad. Knowl. 9(2) (2012) 338-343.

[9] K.A. Bharti, B.L. Sharma, Some ethnoveterinary plants records for Sikkim Himalaya, Indian J. Tradit. Knowl. 9(2) (2010) 344-346.

[10] M.R. Naik, V. Venugopalan, P. Kumaravelayutham, Y.L. Krishnamurthy, Ethnoveterinary uses of medicinal plants among the Lambani community in Chitradurga district, Karnataka, India, Asian Pac. J. Trop. Biomed. 2(Suppl 2) (2012) S470-S476

[11] N. Rajakumar, M.B. Shivanna, Traditional veterinary healthcare practices in Shimoga district of Karnataka, India, Indian J. Trad. Knowl. 11(2) (2012) 283287.

[12] S. Kiruba, S. Jeeva, S.S.M. Dhas, Enumeration of Ethnoveterinary plants of Cape Comorin, Tamil Nadu, Indian J. Trad. Knowl. 5(4) (2006) 576-578.

[13] B.A. Dar, R.K. Verma, Anaiat-ul-Haq, Ethno veterinary value of some plant species utilized by rural people of Jhansi district, Bundelkhand region, Res. J. Agri. Sci. 2(2) (2011) 321-324.

[14] A. Selvaraju, M. Ayyanar, S.S. Rathinakumar, T. Sekar, Plants used in ethnoveterinary medicine by Malayali tribal in Salem district of Tamil Nadu, India, J. Med. Plants Res. 3(3) (2011) 1-6.

[15] J.R. Mulay, V. Dinesh, P.P. Sharma, Study of some ethno-veterinary medicinal plants of Ahmednagar district of Maharashtra, India, World J. Sci. Technol. 2(6) (2012) 15-18.

[16] M.P. Pragada, G.M.N. Rao, Ethnoveterinary medicinal practices in tribal regions of Andhra Pradesh, India, Bangladesh J. Plant Taxon. 19(1) (2012) 7-16. 